CLIMBING THE LADDER

Four of science's leaders - the head of a university college, and the directors of a medical research charity, an observatory, and a pharmaceuticals company tell how they made it to the top pp408-409
FROM DESK TO BENCH

A few dynamic administrators find the time to keep their hand in at scientific research - and discover that lab work gives them added credibility when it comes to decision-making p410

\title{
How head-hunters track down the winners for science's top jobs
}

\section{The star performers are not just head-hunted, they can write their own job descriptions. But how can a scientist reach this enviable position?}

$\mathrm{B}$ usiness is booming for head-hunters. More and more directors of industrial research and development, heads of research organizations and university vicechancellors are being selected through executive search agencies - companies that typically charge $\mathfrak{2} 35,000$ (US $\$ 56,200$ ) to find someone capable of filling a top job with a salary of $\mathfrak{E} 100,000$

According to Kennedy Information which calls itself "the leading information source on management consulting and executive search agencies" - the worldwide revenue of the executive search industry has grown rapidly, from around $\$ 3.5$ billion in 1993 to $\$ 7.3$ billion in 1997.

One of the biggest players is Korn/Ferry International, specializing in areas including advanced technology, education, energy and health care. It has 70 offices in 40 countries, employing about 1,500 staff who serve more than 4,000 clients. It floated on the New York stock exchange this year. Half its revenue comes from the United States, 30 per cent from Europe, 10 per cent from Asia and 10 per cent from Latin America.

\section{Defining the job}

The first task of an executive search agency is to identify exactly what a job entails. "For every appointment, we have a briefing meeting with the client to learn about the job and the working environment, and to identify what a successful appointment would look like," says Peter Bassett, UK managing partner of health-care practice at Korn/Ferry International in London. "We ask what success would look like at six months and at three to four years. By asking the client the question in that way it helps them define their thinking and therefore the profile of the ideal candidate. We ask why candidates would want to do the job and what the challenges are."

Having identified the job description, "The next question is: where would the person who could do that job be now?" says Bassett. "They could be in academia or industry. We can consult a database and conduct a

search by contacting people who have helicopter vision on who is new and upcoming. Another way is to look at an organization and identify who does what within it."

Most executive search agencies rely on sources to suggest names. Many senior researchers are accustomed to being contacted by agency consultants, most of whom have spent around ten years working in the com-

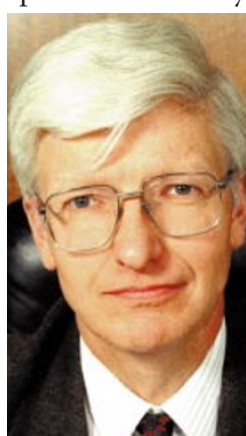

Llewellyn Smith: 'agencies often call' munities from which they now recruit. "I have been approached many times," says Chris Llewellyn Smith, the provost and president of University College London. "Half the time they ask whetherI know anyone who might be interested in a particular job. The other half of the time, they are more direct - would I be interested?"

Agencies typically contact up to 150 people, gathering informal references and getting a feel for the remuneration that would be required. "We confirm a recommendation by careful reference taking," says Bassett. The agency passes a shortlist of around 12 names to the client for interview.

Executive search agencies first appeared in the United States about 50 years ago. Egon Zehnder has been around for 35 years, and has 50 offices in 40 countries. It specializes in areas including the life sciences, chemicals and high technology.

"There are far more similarities than differences between the use of executive search agencies in the US and Europe and Asia," says Ron Tracy, a consultant in the firm's life sciences practice group covering the United States, a larger and more heterogeneous market than the United Kingdom. In Asia, he says, many companies remain local, but there are an increasing number able to compete in regional and international markets, so recruitment will become more international.

As recruitment searches become more international, the ability to adapt to different cultures is becoming vital to success in a senior position, according to Laurence Monnery, a consultant in Egon Zehnder's European life sciences practice group. "Searches are international as the candidate could be anywhere," she says. "The top researchers are not necessarily the best managers and leaders. Whatever the technical skills required, we will always look at other aspects - people management, leadership and the ability to adapt to different cultures."

\section{A place on the board}

Egon Zehnder also recruits non-executive board members for biotech companies. "Companies are placing more emphasis on having strong independent board members, and we look to recruit these from academia. It is important that the candidate has the ability to stand back, advise and challenge."

Founded in 1953, Heidrick and Struggles was one of the first executive search agencies. It now has 59 offices around the globe, with clients including start-up companies, universities and hospitals, and a revenue of $\$ 330$ million (including subsidiary firms) in 1998. Although most executive search agencies do not provide recruitment services for individuals seeking work, Heidrick and Struggles has recently started an individual placement service for technology professionals.

An alternative for researchers seeking a new lease of life is a temporary placement as a troubleshooter. "There are a variety of scenarios in which we are called in," says Cynthia Larbey, managing director of People in Health, a British firm based in Woodbridge,

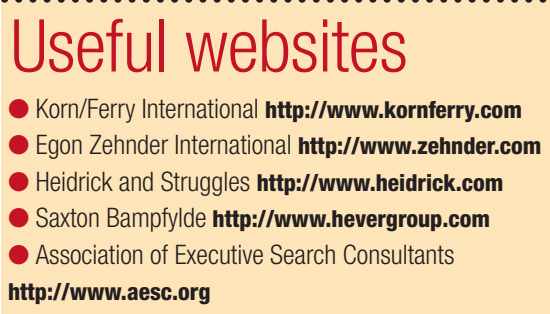


Suffolk, which operates across Europe. "For example, we had the medical director of a biotech company which was coming up for a product launch off with a long-term illness at the most crucial time for the company. Fortunately we had a chap with experience in the right area on our books." People in Health has more than 130 people poised to take a temporary job. "They are people who have taken early retirement or been made redundant but who aren't ready to take up the golf clubs," says Larbey. "Plus 40- to 45-year-olds who have made a lifestyle choice over the way in which they want to work. But I don't employ people between jobs. Only five per cent of those who approach the company are accepted."

Although industry is still more likely to use head-hunters than academic institutions, the public sector does use them to fill senior positions. "We have placed some 30 university vice-chancellors in the UK in the past three or four years," says Paula Alexander of Saxton Bampfylde. "The qualities which clients seek vary hugely. Some universities are looking for a real research person, as their research rating is poor and they want to get it rocketing. Others are looking for a business person as they have financial problems."

The Wellcome Trust, the world's largest medical research charity, uses executive search agencies. "Most organizations are moving towards using head-hunters," says Mike Dexter, the trust's director. "Headhunters can make phone calls which the appointing organization can't without it appearing to be a firm job offer. Head-hunting is an informal peer-review process but it is an informed peer-review process. There is a selection informed by debate."

Of course there are ways to secure a senior appointment without using head-hunters. Organizations can appoint their own search committees that can use the same techniques as head-hunters. And in many cases the ideal candidate is obvious and can be approached direct. Some companies identify who they want and design a job in collaboration with the person they recruit. Peter Goodfellow, who runs SmithKline Beecham's drug discovery programme, secured his job in this way.

\section{Chris Llewellyn Smith \\ University College London}

Chris Llewellyn Smith became provost and president of University College London (UCL) five months ago. Before that, he was director-general of CERN, the European Laboratory for Particle Physics, in Geneva.

Hailed as an outstanding diplomat, Llewellyn Smith had been credited with laying the foundations for European particle physics by persuading governments to fund the Large Hadron Collider, due for completion in 2005. He convinced countries that were not members of CERN, in particular the United States and Japan, to help fund its construction. Llewellyn Smith also oversaw a scheme to cut pay by allowing staff to exchange a percentage of their salary for extra leave, freeing up enough money to recruit new young staff.

Llewellyn Smith knew that Derek Roberts, the former head of UCL, was about to retire. He, too, was due to leave his job at the end of his five-year term. As directorgeneral of CERN, he had overseen an organi-

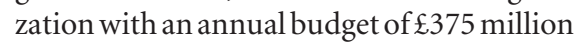
and a staff of 2,800 plus around 6,500 scientific users from universities and research institutions in 50 countries.

After the universities of Oxford and Cambridge, UCL receives the biggest grant for research from the Higher Education Funding Council for England. This money, more than $\mathfrak{E} 60$ million a year, helps to lever income from the research councils, industry and charities.

"I was talking to colleagues based at UCL and they suggested that I might be interested in becoming provost," says Llewellyn Smith. "I then spoke to my predecessor, Derek Roberts, to decide whether or not I was interested in the position." UCL employed Korn/Ferry International to discover who might be interested in the job. A month after his conversation with Roberts, the headhunters approached Llewellyn Smith and told him that his name had come up during talks to identify suitable candidates. The agency then sent him more information about the position and encouraged him to apply.

Llewellyn Smith had three lunches with eight people to discuss the job, his experience and his views on the role of provost. This was followed by a day of formal interviews, after which he was offered the job. His

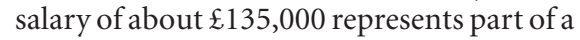
package with a net value comparable to what he was getting at CERN. Being provost of UCL is a distinctly different job, Llewellyn Smith finds. "CERN is project-based and the scientific policy had to be led by the director-general," he says. "Within a university, academic policy is set from the bottom up and my job is to create the right conditions for research - encouraging rather than directing."

Llewellyn Smith now spends much time dealing with funding proposals from the UK government agencies that allocate money to universities. "The funding council breaks up funding into chunks which it gives for schemes such as collaborating with industry on research or for widening access to higher education to people from disadvantaged backgrounds. We feel micromanaged from the centre," he complains.

What advice would he give to a scientist aspiring to a senior appointment? "Think carefully," he says. "It is very difficult to carry out work of your own. However there are compensations, such as learning about other areas of science."

ฝึ 1999 Macmillan Magazines Ltd

\section{Mike Dexter}

Wellcome Trust

Mike Dexter became director of the Wellcome Trust, the world's largest medical research charity, in June 1998. Before that, he was head of the Paterson Institute in Manchester, United Kingdom, where he had spent much of his working life.

"I did know that the position was coming up because I had been approached by a headhunter who wanted me to suggest names," he says. "I told him I wasn't interested as I had recently accepted the job as director of the Paterson Institute." The Wellcome Trust then approached Dexter to seek his views on the future directions of biomedical science. "At that stage, I had no idea that they had a view to my becoming director," he says. "I was very relaxed because it was not a job interview. We discussed the Wellcome Trust's activities and

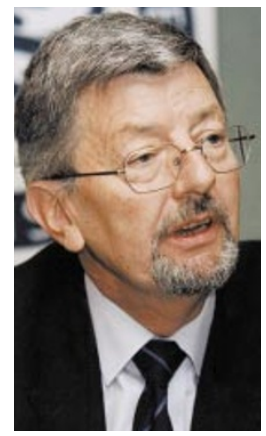

Dexter: 'once-in-a-

lifetime opportunity? positioning in UK science, career development, clinical research, university infrastructure and other research institutes. I suppose I was interviewed without knowing it. After our conversation, the governors discussed what they were looking for in a director and approached me again." Dexter had been based at the Paterson Institute almost continuously for 35 years. $\mathrm{He}$ started in 1963 as a junior research technician, taking a three-year break to get his degree as a mature student, as illness had prevented him from entering university straight from school. He then completed his $\mathrm{PhD}$ at the institute and worked his way up. "Every time I thought about moving, the Paterson Institute came up with a better offer," he says.

However, the Wellcome offer was one that the Paterson could not better. "It was an opportunity that comes up once in lifetime and it was the only job that I would leave Manchester for," says Dexter. "The Wellcome Trust is an organization which has an impact not only on British biomedical science but internationally. As director I could have a strategic input into where biomedical science is going."

Two weeks after Dexter succeeded Bridget Ogilvie as director, Wellcome ploughed $\mathfrak{£ 3 0 0}$ million into refurbishing decaying university labs and $\mathfrak{E} 100$ million towards a new synchrotron. The UK government simultaneously pledged an extra $\mathfrak{E 3 0 0}$ million for this refurbishment and $\mathfrak{E} 300$ million for the synchrotron. Further government money, directed through the research councils and the Department for Education and Employment, took the total increase to $£ 1.4$ billion over three years. Dexter and his predecessor 
have been credited with levering this public money using Wellcome Trust funds.

"It was an exciting time," he says. "I thought it couldn't always be like that but I have been involved in ongoing initiatives. The job is so varied. One day I can be meeting senior politicians at ministerial level, on others the chief scientific adviser to the government, the director-general of the research councils, the heads of the research councils, and overseas scientists."

Money is not a prime motivator, says Dexter. Indeed, other scientists believe that his salary of between $\mathfrak{E} 130,000$ and $\mathfrak{E} 140,000$ is modest for what Dexter could command. But Dexter has boosted the pay of his researchers by up to 30 per cent, and has called on the government to increase pay for university researchers. "We can only exploit people so much," he says.

The only downside to the job is that Dexter can no longer run an active research group. "The hardest decision was to move over into what is essentially administration," he says. "I certainly would not encourage a young researcher to go into administration while they are still doing their best research. I miss doing science but it is enormously exciting to develop strategies and policies for biomedical science internationally."

\section{Catherine Cesarsky \\ European Southern Observatory}

Catherine Cesarsky became director-general of the European Southern Observatory (ESO), in Garching, near Munich, this month. Before that, she was head of the department of "science of matter" at the French Atomic Energy Commission (CEA), conducting basic research in physics, chemistry, astrophysics and Earth sciences.

"I had a phone call from the ESO search committee, which had been appointed to find a new director-general to succeed Riccardo Giacconi," says Cesarsky. The committee had drawn up a shortlist of suitable candidates after consulting key figures in the

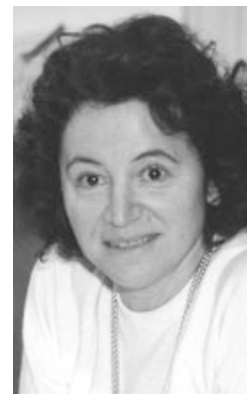

Cesarsky: 'this is an exciting adventure'.

\section{astronomy communi-} ty. Cesarsky's high profile had ensured her presence on the shortlist - she is vice-president of the International Astronomical Union, vice-president of the European Space Agency council and principal investigator for one of the experiments on board the agency's Infrared Space Observatory, and editor-in-chief of Astronomy and Astrophysics. In fact, her profile is such that a full-page article about her appeared in last December's French edition of Vogue, dedicated to the theme of science and fashion.

Each of the eight member states of ESO sent two representatives to interview Cesarsky simultaneously. "There was no-one on the board that I had not met before, they were all people with whom I have had working interfaces, so it was not intimidating at all," she says. After an interview lasting one hour, she was offered the job. One of the conditions set by Cesarsky was that she should still be able to conduct research. "I have to have my science to be happy," she says. "If I am happy, then I can manage people well."

About 400 people work for the ESO, which has a budget of DM1.5 million (US\$800,000). When Cesarsky worked for the CEA, she was responsible for some 3,000 staff and had a budget of FF2 billion ( $\$ 317$ million). Yet she is getting paid more at the ESO. "I was well paid at the CEA and I have received a pay rise in coming to ESO," she says. "However it is offset by extra expenses: my children are in France and I need to maintain a house there." She estimates her salary as $\mathfrak{E} 90,000$.

Her international lifestyle propelled her towards accepting the job. Born in France, she was raised in Argentina and completed her PhD and a postdoc in the United States. However, she had been living in France for the past 25 years and was keen to move on. "My husband and I are excited by change," she says. "Our children are now at the age when they can be left alone and my parents both died recently. This job represents a new lease of life, a new adventure and a new opportunity. I have a special fondness for ESO. It is a wonderful time, to see what will come out of the Very Large Telescope."

\section{Peter Goodfellow}

\section{SmithKline Beecham}

Peter Goodfellow joined SmithKline Beecham three years ago and now runs its drug discovery programme. Before that, he was professor of genetics at the University of Cambridge.

SmithKline Beecham created a job specifically for Goodfellow, a renowned expert in human genetics, to tempt him to join the company. "I was approached by George Post, who was then head of research and development at SmithKline Beecham," says Goodfellow. "We met at a conference. I was walking down a corridor and he asked me whether I was interested in joining SB. I visited the company sites in the US and UK, and we worked together to define a job that was appropriate."

Goodfellow had gained his first degree at the University of Bristol, in the same department in which Post had completed his PhD. "There was a cultural history," says Goodfellow. "Post knew who I was and I knew who he

was." After graduating, Goodfellow went to the University of Oxford to do his PhD, followed by three years at Stanford University, California, and 13 years at the Imperial Cancer Research Fund in the United Kingdom.

During his time in the United States, he gained some industrial experience and, after returning to the United Kingdom, he founded Hexagen as a spin-off company from the University of Cambridge. In August 1998, Hexagen was bought by the US company

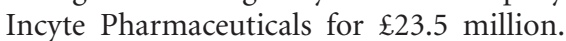
Having a 2 per cent stake in Hexagen, Good-

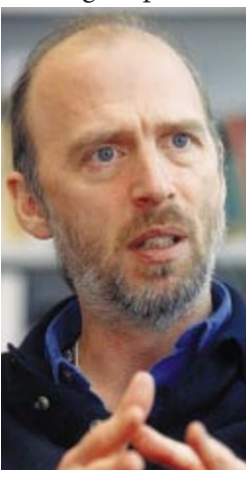

Goodfellow: 'I feel like a student again'. fellow made the best

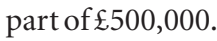

"SmithKline Beecham were interested in my skill base in human genetics but I was keen not to be its 'expert in genetics' - I wanted to make drugs," says Goodfellow. He was taken on to run a platform of genetics technologies and within three years was promoted to head of research. Responsible for some 2,000 scientists on three sites, he is cagey about his earnings. People working in similar jobs are likely to earn up to $\mathfrak{k} 175,000$ a year.

"The way in which knowledge is transformed into doing good for people is my major motivation in working for the company," he says. "There is something of a buzz about working in health and welfare." Goodfellow views his responsibility for areas of science outside his speciality as a bonus. "It is wonderful to have the opportunity to learn across such a wide area of expertise. Most of the things I have responsibility for I know little about. I feel like a graduate student again."

About 30 per cent of Goodfellow's time is spent on strategic issues within research and development and the company as a whole. A further 30 per cent, he estimates, is spent reviewing science, and 30 per cent administering his group. Goodfellow devotes his remaining time to academic research and other responsibilities - he is a trustee of the Imperial Cancer Research Fund, for example. "You have to make a decision about how close you want to be to the everyday science," he says. "In a senior position, it is not possible to spend the same amount of time doing research. There are people who can still run a lab but it can't be done as if it were the only priority. You have to accept the fact that you are going to spend time dealing with the administration and politics of an organization - there are a lot of interfaces at which you need to work."

Alison Goddard Alison Goddard is a reporter on The Times Higher Education Supplement.

e-mail: alison.goddard@newsint.co.uk 